\title{
Some investigations on the clinical and biochemical alterations associated with dizinon toxicity in Clarias gariepinus
}

\author{
Safinaz A. Bakhshwan ${ }^{1}$, Mohamed S. Marzouk, ${ }^{2}$ Magdy I. Hanna, ${ }^{2}$ \\ and Heba, S. Hamed ${ }^{1}$ \\ 1-Department of Zoology, Girls college for Arts, Science \& Education, \\ Ain Shams University, Egypt. \\ 2-Department of Fish Diseases and Management, Faculty of Veterinary \\ Medicine, Cairo University, Egypt.
}

\begin{abstract}
$\mathrm{D}$ iazinon is widely and effectively used in agriculture as well as in domestic and aquaculture aspects. As a result of its widespread application, its ecotoxicity study is needed to determine its effects on the aquatic organisms and its potential impact as an environmental contaminant. In this study, the half lethal concentration $\left(\mathrm{LC}_{50}\right)$ of diazinon for Clarias gariepinus was calculated. Diazinon toxicity was evaluated through acute and chronic exposures of fish to $1 / 2$ and $1 / 10$ the calculated $\mathrm{LC}_{50}$ for $1 \mathrm{w} \& 6 \mathrm{w}$ respectively. Results showed that the $\mathrm{LC}_{50} / 96 \mathrm{~h}$ was $5.98 \mathrm{ppm}$. The effects of both acute and chronic exposures revealed clinical abnormalities in the form of nervous and respiratory disorders manifested by erratic swimming and/or circling, rapid opercular movements and abnormal skin pigmentation that appeared in the form of skin fading. A significant increase in cortisol, glucose, AST \& ALT activities, urea, uric acid, creatinine and serum $\mathrm{Ca}^{++}$levels were recorded. Furthermore, diazinon exposures were associated with an inhibition of cholinesterase activity, a decrease in total protein concentration in serum with a reduction in both albumin and globulin. This study declared that diazinon is an extremely toxic organophosphate pesticide for C. gariepinus, its improper application often results in contamination of the environment and consequently in deleterious health effects. So, strict precautions should be followed.
\end{abstract}

Key words: diazinon, clinical signs, biochemical parameters, residues.

\section{INTRODUCTION}

Pesticides are occasionally used indiscriminately in large amounts causing environmental pollution, therefore, they are of great concern. Residual amounts of organophosphate (OP) and organochlorine (OC) pesticides have been detected in the soil, water bodies, vegetables, grains and other foods products (John et al., 2001).

Diazinon (O,O - diethyl-O-[2- isopropyl-6- methyl- 4- pyrimidinyl ] phosphorothioate) (Garfitt et al., 2002), is an organophosphorous insecticide (OP) and acaricide that had been developed in the early 1950 (Watterson, 1999). 
The trade names of diazinon include Knox - out, Diazinon and Basudin (EPA, 2004) with abroad range of activities which inhibit acetylcholinesterase activity.

Diazinon acts as a contact stomach and respiratory poison. It is used throughout the world to control a wide range of sucking and chewing insects and mites on a range of crops including deciduous fruit trees; citrus fruit, bananas, vegetables, potatoes, beet, sugar cane, coffee, cocoa, tea, tobacco, cotton and rice. It is used to control agricultural soil - dwelling insects and is applied as a sheep dip to control ectoparasites such as sheep scab (Tomlin,1997).

Diazinon with other organophosphorous and carbamates, poison human and insects through their effects on nerve enzymes. Diazinon combines chemically with acetylcholinesterase enzyme and inactivates it. It affects a wide range of non target organisms, like invertebrates, fishes, birds and mammals, especially those inhabiting aquatic environment. This may be attributed to its aquatic distribution (Burkepile et al., 2000). Although the aquatic environment is not the target for the use of such pesticide, the results of a number of monitoring studies have evidenced the presence of diazinon and its metabolite, diazoxon, in surface waters ( Baily et al., 2000 \& Devlaming et al., 2000 ). This why great attention has been paid to the effect of diazinon on fishes. The major biochemical response to the effect of diazinon in fishes is the inhibition of a number of enzymes above all acetylcholinesterase.(Hamm et al.,1998).

So, this study was designed to display the toxic effects of diazinon in $C$. gariepinus through determination of its $\mathrm{LC}_{50} 96 \mathrm{~h}$ value of and its impact on the biochemical profile and the stress indicators as well as investigation of the residual effect in liver, gills and muscles of exposed fish.

\section{MATERIAL AND METHODS}

\section{Fish and rearing conditions:}

A total number of 150 of live C. gariepinus with average body weight $400 \pm 50 \mathrm{~g}$ were obtained from Abassa fish farm, El-Sharkya governorate, Egypt. They were transferred to the laboratory of Fish Diseases and Management Department, Faculty of Vet. Med., Cairo University in plastic bags containing aerated water. The fish were kept in identical glass aquaria aerated with air pump at temperature of $22 \pm 2^{\circ} \mathrm{C}$, supplied with dechlorinated water and left for 2 weeks for acclimatization. The fish were fed commercial ration containing 30\% protein. They were examined clinically to assure the absence of any abnormalities or external lesions.

\section{The chemical used:}

Diazinon is a colorless to dark brown liquid; produced by Ciba-Geigy Corp. P.O. Box 18300. Greensboro, NC 27419-8300. The molecular weight of diazinon is 304.35 . 


\section{Chemical name and structure:}

O,O-diethyl O-2-isopropyl-6-methyl(pyrimidine-4-yl) phosphorothioate

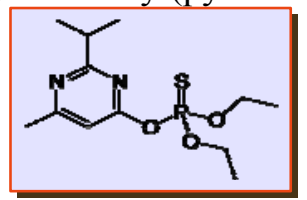

\section{Determination of 96 hours half lethal concentration $\left(\mathrm{LC}_{50}\right)$ of diazinon:}

Estimation of the concentration of diazinon which is most likely to cause $50 \%$ mortality as (LC50) for 96 hours exposure was calculated using Arithemetric method (Dede, 1992).

\section{Experimental design:}

One hundred and twenty (120) Clarias gariepinus were categorized into three groups. The $1^{\text {st }}$ group was exposed to $1 / 2 \mathrm{LC}_{50}$ of diazinon for 1 week (acute exposure) The $2^{\text {nd }}$ group was exposed to $1 / 10 \mathrm{LC}_{50}$ of diazinon for 6 weeks (chronic exposure), while the $3^{\text {rd }}$ group served as control. Blood and tissues samples were obtained from all groups at the $3^{\text {rd }}, 5^{\text {th }}$ and $7^{\text {th }}$ day in case of acute exposure and at the $3^{\text {rd }}, 7^{\text {th }}, 10^{\text {th }}, 14^{\text {th }}, 21^{\text {st }}, 28^{\text {th }}, 35^{\text {th }} \& 42^{\text {nd }}$ day in case of chronic exposure

\section{Clinical investigation and postmortem examination:}

The exposed fish were kept under proper observation during the period of study for any clinical abnormalities \& PM lesions or deaths according to the method described by Amlacher (1970).

Biochemical examination: Blood samples were taken from the fishes, allowed to clot at room temperature and centrifuged at 3000 r.p.m. for 15 min. to separate serum. Serum samples were used to determine serum cholinesterase according to the method described by Kendel \& Bottger (1967). The plasma glucose was measured by using Stanbio kit according to the method described by Trinder (1959). Cortisol was measured by using DSL-2100 active ${ }^{\circledR}$ cortisol RIA kit according to the method described by Yalow and Berson (1971). Serum AST\&ALT activities were estimated calorimetrically using Stanbio kit as described by Reitman \& Frankel (1957). Creatinine was measured by the Calorimetric method described by Fabiny and Einghausen (1971). Urea was estimated according to Henry et al. (1974).Uric acid was measured by using enzymatic determination method according to Barham \&Tinder (1972). Total protein was determined by Biuret test according to Gornal et al. (1949). Serum albumin was measured by using Stanbio kit as described by Dumas \& Biggs (1972). Globulin was calculated according to the method described by Coles (1974). A / G ratio was calculated from the serum albumin present in relation to the amount of globulin. The plasma calcium was estimated by the calorimetric method described by Biggs \& Moorehead (1974).

Residual analysis of diazinon: the residues of diazinon in liver, gills and muscle of exposed fish were determined according to Mills et al. ( 1972) using 
high Performance Liquid Chromatography.

Statistical Analysis: the data obtained in this study were statistically analyzed using analysis of variance, one way "ANOVA", and Duncan's multiple test according to the method described by SPSS (2004).

\section{RESULTS AND DISCUSSION}

Pesticides induce changes in the chemical composition of natural aquatic environments which can affect many of the non - target organisms, particularly fish (Adams \& Greeley, 2000).

To study the toxic effects of diazinon on C. gariepinus, it was necessary to determine the half lethal concentration $\left(\mathrm{LC}_{50}\right)$ of diazinon . Results revealed that the $\mathrm{LC}_{50}$ of diazinon was $5.98 \mathrm{ppm}$ (Table1).

Table (1): Half lethal concentration $\left(\mathrm{LC}_{50}\right)$ OF Diazinon in C. gariepinus:

\begin{tabular}{|c|c|c|c|c|c|}
\hline Conc.(ppm) & Conc.(diff) & No.alive & No.dead & Mean dead & B x E \\
\hline 0.00 & 0.00 & 8 & 0 & 0 & 0 \\
1.65 & 1.65 & 4 & 4 & 2 & 3.3 \\
3.3 & 1.65 & 4 & 4 & 4 & 6.6 \\
6.6 & 3.3 & 3 & 5 & 4.5 & 14.85 \\
13.2 & 6.6 & 1 & 7 & 6 & 39.6 \\
26.4 & 13.2 & 0 & 8 & 7.5 & 99 \\
\hline Total & & & & & 163.35 \\
\hline
\end{tabular}

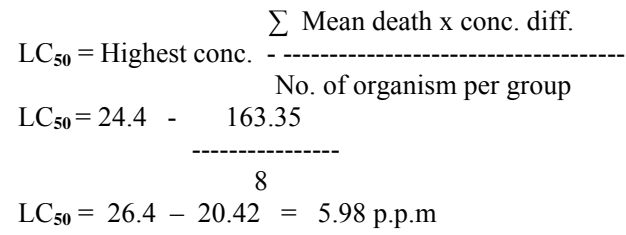

This result was nearly similar to those of Adedeji et al. (2008) who recorded that $\mathrm{LC}_{50}$ value of diazinon for C. gariepinus was $6.6 \mathrm{ppm}$. But it is higher than that of Palacio et al. (2002) recorded for young red tilapias (3.85 ppm), of Köprücü et al.(2006) (4.14 ppm) for European catfish (Silurus glanis L.), of Máchová et al. (2007), for guppy (Poecilia reticulata) (3 ppm) but much lower than that of the common carp (Cyprinus carpio L.) (10-25 ppm). The difference in results may be attributed to factors causing the selective toxicity of diazinon for various fish species which are different inhibition of acetyicholinesterase, different inhibition detoxification and absorption levels (Oh et al., 1991). Beside that, the toxic effect changes with respect to species and size of fish and the duration of exposure (Oh et al., 1991 \& Dutta et al., 1995).

To investigate the acute and chronic toxicity of diazinon on $C$. gariepinus, fish were exposed to $2.99 \mathrm{ppm},\left(1 / 2\right.$ of the determined $\left.\mathrm{LC}_{50}\right)$ of 
diazinon for 1 week as a short term or acute exposure and $0.6 \mathrm{ppm}(1 / 10$ of the determined $\mathrm{LC}_{50}$ ) for 6 weeks as a long term or chronic exposure.

Clinical signs and postmortem findings in C. gariepinus associated with acute toxicity of diazinon were manifested by nervous signs including, abnormal swimming behaviour in the form of erratic swimming with or without circling, abnormal skin pigmentation in the form of fading, rapid opercular movement and excessive mucous secretion (photo,1). Different degrees of congestion especially in the spleen and haemorrhage in all internal organs of the exposed fish (Photos 2, 3\&4). Enlargement of liver and distension of gall bladder were also recorded as prominent lesions (Photos, 5\&6).

In chronic toxicity, the clinical signs and lesions were more or less similar to those of acute toxicity except for the mortality percent which was $5 \%$ of the chronically exposed fish compared to $10 \%$ in acute exposed fish . The observed clinical signs were similar to those of Ural \& koprucu (2006) and Kavitha \& Rao (2007). These signs might be attributed to the stress condition associated with the toxicant exposure (Arunachalam et al. 1980; Arunachalam \& Palanichamy, 1982). These observations could be explained through understanding the mechanistic action of diazinon by inhibiting the AchE activity, by phosphorylation of the serine hydroxyl group in the substrate - binding domain of the enzyme, which results in accumulation of acetylcholine (Fulton \& Key, 2001). In this aspect, this explanation is supported to the finding of Zinkl et al. (1991) who stated that the death of fish is caused by asphyxiation due to multiple factors, namely paralysis of muscles, that provide the force for movement of water through the gills, cholinergic - induced bradycardia and shunting of blood through filamentous sinuses because of increased branchial vascular resistance. The observed abnormal skin pigmentation may be due to the neurotoxic effect of diazinon, where the pigmentation in fish is nervously controlled. The obtained results mostly agree with those of Köprücü et al.(2006) and Hanna and Sahar ( 2007) . They disagreed with the results demonstrated by Adedeji et al.(2008), who noticed extensive pigmentation mainly on the dorsal part of the body of the exposed fish exposed to $\left(\mathrm{LC}_{50}\right)$ and $\left(\mathrm{LC}_{25}\right)$ of diazinon for 96h. This observation may be due to the difference in both pesticide concentration and exposure period.

The mortality pattern noticed in this experiment could be explained by the concentration / time of exposure relationship in which a long term exposure is required to kill the fish regardless of the chemical concentration. It could be also attributed to the stoppage of feeding of the exposed fish by the time with the final result of severe weakness and mortality of exposed fish (Arunachalam et al., 1980).

Changes in biochemical parameters of exposed fish, may often be among the more sensitive indicators of early changes due to the hazardous exposure to insecticides (Safi, 1996). 
Concerning serum ALT and AST, results demonstrated in Tables2-3a\&b revealed a significant increase in the diazinon exposed fish during the acute and chronic exposures compared with the control group. These results agreed with those demonstrated by Radwan \& El - Said (2006) and Agrahari et al.(2007). As it is known, liver of vertebrates generally and fish particularly is the principle organ of detoxification as reviewed by Freeman et al. (1983). So, the increase in ALT and AST transaminases might be attributed to tissue damage, particularly liver (Palanivelu et al., 2005).The elevation of these enzymes in the extracellular fluid or plasma is a sensitive indicator of even cellular damage (Van der Oost et al., 2003; Palanivelu et al., 2005). Thus, the measurement of transaminases and phosphatase activities in blood plasma of fish can be used as indicator for pesticide toxicity (Agrahari et al., 2007) . On the other hand, the obtained results disagreed with those of Rao (2006a) and Rao (2006c). This disagreement could be attributed to multi factors including different fish species and concentration of diazinon as well as the nature of the pesticides used.

Concerning the results of total protein, albumin, globulin and $\mathrm{A} / \mathrm{G}$ ratio (Tables2-3a\&b), proteins are the most important and abundant macromolecules in living beings, which play a vital role in architecture and physiology of the cell and in cellular metabolism (Mommsen \& Walsh, 1992).

Also proteins play an important role in the metabolism and regulation of water balance (Heath, 1995). Results revealed total hypoproteinaemia, hypoglobulinaemia, hypoalbuminaemia and increased $\mathrm{A} / \mathrm{G}$ ratio in exposed fish during short and long term of exposures, in comparison with the control group .

Table (2): Effect of acute exposure to diazinon on liver and kidney functions of Clarias gariepinus.

\begin{tabular}{|c|c|c|c|c|c|c|c|c|c|}
\hline parameter & $\begin{array}{c}\text { (AST) } \\
(\mathrm{u} / \mathrm{l})\end{array}$ & $\begin{array}{c}\text { (ALT) } \\
(\mathrm{u} / \mathrm{l})\end{array}$ & $\begin{array}{c}\text { Total } \\
\text { protein } \\
(\mathrm{g} / \mathrm{dl})\end{array}$ & $\begin{array}{c}\text { Albumin } \\
(\mathrm{g} / \mathrm{dl})\end{array}$ & $\begin{array}{l}\text { Globulin } \\
\text { (g/dl) }\end{array}$ & A/G ratio & $\begin{array}{c}\text { Creatinine } \\
\text { (mg/dl) }\end{array}$ & $\begin{array}{c}\text { Urea } \\
\text { (mg/dl) }\end{array}$ & $\begin{array}{c}\text { Uric acid } \\
(\mathrm{mg} / \mathrm{dl})\end{array}$ \\
\hline Control & $14.57 \pm 1.38^{\mathrm{c}}$ & $13.83 \pm 1.28^{\mathrm{c}}$ & $5.17 \pm 0.38^{\mathrm{a}}$ & $2.03 \pm 0.03^{\mathrm{a}}$ & $3.13 \pm 0.41^{\mathrm{a}}$ & $0.67 \pm 0.12^{\mathrm{ab}}$ & $0.27 \pm 0.33^{b}$ & $13.57 \pm 1.07$ & $2.03 \pm 0.13^{\mathrm{b}}$ \\
\hline $3^{\text {rd day }}$ & $26.97 \pm 1.20^{\mathrm{b}}$ & $22.10 \pm 1.87^{\mathrm{b}}$ & $3.93 \pm 0.03^{\mathrm{ab}}$ & $1.77 \pm 0.03^{\mathrm{b}}$ & $2.17 \pm 0.03^{\mathrm{ab}}$ & $0.82 \pm 0.03^{\mathrm{a}}$ & $0.30 \pm 0.10^{\mathrm{b}}$ & $14.77 \pm 1.31^{\mathrm{b}}$ & $2.87 \pm 0.20^{\mathrm{ab}}$ \\
\hline $5^{\text {th }}$ day & $34.47 \pm 1.09^{\mathrm{a}}$ & $26.83 \pm 0.69^{b}$ & $3.70 \pm 0.56^{\mathrm{bc}}$ & $1.17 \pm 0.09^{\mathrm{c}}$ & $2.53 \pm 0.48^{\mathrm{ab}}$ & $0.48 \pm 0.06^{\mathrm{b}}$ & $0.50 \pm 0.12^{\mathrm{b}}$ & $14.37 \pm 0.79^{b}$ & $2.70 \pm 0.47^{\mathrm{ab}}$ \\
\hline $7^{\text {th }}$ day & $31.70 \pm 0.81^{\mathrm{a}}$ & $31.93 \pm 1.87^{\mathrm{a}}$ & $2.57 \pm 0.38^{\mathrm{c}}$ & $0.90 \pm 0.12^{\mathrm{d}}$ & $1.67 \pm 0.26^{\mathrm{b}}$ & $0.54 \pm 0.02^{\mathrm{b}}$ & $0.80 \pm 0.58^{a}$ & $\underset{\mathrm{a}}{18.07 \pm 0.55}$ & $3.27 \pm 0.41^{\mathrm{a}}$ \\
\hline
\end{tabular}

Data presented as means \pm SE $(n=9)$. Values within rows with no common superscripts are significantly different, while those with common superscripts are not significantly different $(p<0.05)$, according to one way ANOVA followed by Duncan's Test 
Table (3a): Effect of chronic exposure to diazinon on liver and kidney functions of Clarias gariepinus.

\begin{tabular}{|c|c|c|c|c|c|c|c|c|c|}
\hline Days & $\begin{array}{c}\text { (AST) } \\
(\mathrm{u} / \mathrm{l})\end{array}$ & $\begin{array}{c}\text { (ALT) } \\
(\mathbf{u} / \mathbf{l})\end{array}$ & $\begin{array}{c}\text { Total } \\
\text { protein } \\
\text { (g/dl) }\end{array}$ & $\underset{(g / d l)}{\text { Albumin }}$ & $\begin{array}{l}\text { Globulin } \\
\text { (g/dl) }\end{array}$ & A/G ratio & $\begin{array}{c}\text { Creatinine } \\
\text { (mg/dl) }\end{array}$ & $\begin{array}{l}\text { Urea } \\
\text { (mg/dl) }\end{array}$ & $\begin{array}{c}\text { Uric acid } \\
\text { (mg/dl) }\end{array}$ \\
\hline Control & $14.57 \pm 1.38^{d}$ & $13.83 \pm 1.28^{\mathrm{c}}$ & $5.17 \pm 0.38^{\mathrm{a}}$ & $2.03 \pm 0.03^{\mathrm{a}}$ & $3.13 \pm 0.41^{\mathrm{a}}$ & $0.67 \pm 0.12^{\text {ab }}$ & $0.27 \pm 0.03^{c}$ & $13.00 \pm 1.07^{b}$ & $2.03 \pm 0.13^{c}$ \\
\hline $3^{\text {rd day }}$ & $19.93 \pm 2.41^{\mathrm{c}}$ & $18.07 \pm 0.99^{c}$ & $3.77 \pm 0.09^{\mathrm{b}}$ & $1.57 \pm 0.09^{\mathrm{b}}$ & $2.20 \pm 0.12^{\mathrm{bc}}$ & $0.72 \pm 0.07^{\mathrm{ab}}$ & $0.33 \pm 0.09^{\mathrm{bc}}$ & $15.20 \pm 1.97^{\mathrm{ab}}$ & $2.30 \pm 0.12^{\mathrm{bc}}$ \\
\hline $7^{\text {th }}$ day & $23.43 \pm 1.50^{\mathrm{bc}}$ & $25.77 \pm 1.12^{\mathrm{b}}$ & $2.43 \pm 0.38^{\mathrm{d}}$ & $0.77 \pm 0.20^{c}$ & $1.67 \pm 0.26^{c}$ & $0.47 \pm 0.15^{\mathrm{ab}}$ & $0.40 \pm 0.10^{\mathrm{bc}}$ & $15.90 \pm 1.48^{\mathrm{ab}}$ & $2.50 \pm 0.25^{\mathrm{bc}}$ \\
\hline $10^{\text {th }}$ day & $26.30 \pm 0.87^{b}$ & $26.30 \pm 1.85^{\mathrm{b}}$ & $2.63 \pm 0.12^{\mathrm{d}}$ & $0.87 \pm 0.09^{c}$ & $1.77 \pm 0.18^{c}$ & $0.50 \pm 0.10^{\mathrm{ab}}$ & $0.53 \pm 0.17^{\mathrm{abc}}$ & $14.50 \pm 1.23 b$ & $2.73 \pm 0.12^{\mathrm{ab}}$ \\
\hline
\end{tabular}

Data presented as means $\pm \operatorname{SE}(n=9)$. Values within rows with no common superscripts are significantly different, while those with common superscripts are not significantly different $(p<0.05)$, according to one way ANOVA followed by Duncan's Test

Table (3b): Effect of chronic exposure to diazinon on liver and kidney functions of Clarias gariepinus.

\begin{tabular}{|c|c|c|c|c|c|c|c|c|c|}
\hline Days & $\begin{array}{c}\text { (AST) } \\
(\mathrm{u} / \mathrm{l})\end{array}$ & $\begin{array}{c}\text { (ALT) } \\
(\mathrm{u} / \mathrm{l})\end{array}$ & $\begin{array}{c}\text { Total } \\
\text { protein } \\
(\mathrm{g} / \mathrm{dl})\end{array}$ & $\begin{array}{l}\text { Albumin } \\
(\mathrm{g} / \mathrm{dl})\end{array}$ & $\begin{array}{l}\text { Globulin } \\
(\mathrm{g} / \mathrm{dl})\end{array}$ & $\mathrm{A} / \mathrm{G}$ ratio & $\begin{array}{l}\text { Creatinine } \\
(\mathrm{mg} / \mathrm{dl})\end{array}$ & $\begin{array}{l}\text { Urea } \\
(\mathrm{mg} / \mathrm{dl})\end{array}$ & $\begin{array}{c}\text { Uric acid } \\
(\mathrm{mg} / \mathrm{dl})\end{array}$ \\
\hline $14^{\text {th }}$ day & $24.57 \pm 1.52^{\mathrm{b}}$ & $28.60 \pm 0.59^{\mathrm{ab}}$ & $3.60 \pm 0.30^{\mathrm{bc}}$ & $0.88 \pm 0.09^{\mathrm{c}}$ & $2.72 \pm 0.21^{\mathrm{ab}}$ & $0.32 \pm 0.01^{\mathrm{b}}$ & $0.50 \pm 0.12^{\text {abc }}$ & $15.13 \pm 1.94^{\mathrm{ab}}$ & $2.33 \pm 0.28^{\mathrm{bc}}$ \\
\hline $21^{\text {st }}$ day & $32.63 \pm 0.45^{\mathrm{a}}$ & $31.20 \pm 2.11^{\mathrm{a}}$ & $2.87 \pm 0.33^{\mathrm{cd}}$ & $0.97 \pm 0.18^{\mathrm{c}}$ & $1.90 \pm 0.45^{\mathrm{c}}$ & $0.60 \pm 0.17^{\mathrm{ab}}$ & $0.60 \pm 0.10^{\text {abc }}$ & $13.27 \pm 1.59^{\mathrm{b}}$ & $2.70 \pm 0.06^{\mathrm{ab}}$ \\
\hline $28^{\text {th }}$ day & $31.70 \pm 0.52^{\mathrm{a}}$ & $31.87 \pm 1.47^{\mathrm{a}}$ & $3.80 \pm 0.17^{\mathrm{b}}$ & $1.63 \pm 0.12^{\mathrm{ab}}$ & $2.17 \pm 0.12^{\mathrm{bc}}$ & $0.77 \pm 0.07^{\mathrm{a}}$ & $0.53 \pm 0.17^{\mathrm{abc}}$ & $16.20 \pm 0.70^{\mathrm{ab}}$ & $2.87 \pm 0.03^{\text {ab }}$ \\
\hline $35^{\text {th }}$ day & $34.20 \pm 0.47^{\mathrm{a}}$ & $31.57 \pm 1.94^{\mathrm{a}}$ & $2.77 \pm 0.19^{\mathrm{d}}$ & $1.07 \pm 0.24^{\circ}$ & $1.70 \pm 0.06^{\mathrm{e}}$ & $0.63 \pm 0.18^{\mathrm{ab}}$ & $0.67 \pm 0.12^{\mathrm{ab}}$ & $19.67 \pm 1.11^{\mathrm{a}}$ & $2.87 \pm 0.09^{\mathrm{ab}}$ \\
\hline $42^{\text {nd }}$ day & $31.63 \pm 1.31^{\mathrm{a}}$ & $30.10 \pm 1.01^{\mathrm{ab}}$ & $3.13 \pm 0.09^{\text {bcd }}$ & $1.03 \pm 0.12^{\mathrm{c}}$ & $2.10 \pm 0.12^{\mathrm{bc}}$ & $0.50 \pm 0.10^{\mathrm{ab}}$ & $0.83 \pm 0.09^{\mathrm{a}}$ & $19.10 \pm 0.68^{\mathrm{a}}$ & $3.17 \pm 0.24^{\mathrm{a}}$ \\
\hline
\end{tabular}

Data presented as means \pm SE $(n=9)$. Values within rows with no common superscripts are significantly different, while those with common superscripts are not significantly different $(p<0.05)$, according to one way ANOVA followed by Duncan's Test

These results supported those described by Khalaf - Allah (1998) and Hanna and Sahar (2007). The decrease of total protein levels might be due to the increase of cortisol which suppresses the immunoglobulin (Wedemeyer, 1996; Reddy \& Leatherland, 1998). Furthermore, under stress conditions, the protein consumed by fishes is not stored in the body tissue (Baskaran \& Palanichamy, 1990) and hence the exposed fish meet their extra energy requirements from body proteins, which are mobilized to produce glucose, which is made available for fishes by the process of gluconeogenesis (Vasanthi et al., 1990). The depletion of the protein fraction in body tissues may have been due to their degradation and possible utilization of degraded products for metabolic purposes. Moreover, decreased protein content may be attributed to the destruction / necrosis of cells and consequent impairment in protein synthesis machinery (Bradbury et al., 1987). These results disagreed in turn with that of Marie et al. (1998) who recorded a marked increase in serum total protein and 
albumin concentrations of the common carp (C. carpio) exposed to profenofos that may be due to toxicant and fish species difference.

Concerning the results of creatinine, urea and uric acid (Tables 2-3a \& b), they revealed a significant increase in diazinon exposed fish during the short and long term exposure compared to the control group. This can be explained by a disorder of the glomerular filtration rate (G.F.R.) (Hernandez \& Couslon, 1967).The decrease in the rate of excretion of urea nitrogen, produces an increase in the concentration of BUN in plasma as described by Coles ( 1986) . In this respect, the decrease of (G.F.R.), will result in an increase in concentration of serum creatinine (Parums, 1996). The recorded results are in agreement with that of Haggag (2004) and Radwan \& El-Said (2006). However, they, disagreed with that of Hussein et al. (1996) and Mekkawy et al. (1996) who reported that the serum urea level was significantly unaffected in $O$. niloticus exposed to sublethal concentration of atrazine. However, it was reduced in Chrysichthyes auratus exposed to the same herbicide. This difference in results may be due to the difference in fish species and the nature of the pesticide used.

As well recognized about calcium ions in serum, the basic function of electrolytes in the body lies in controlling fluid distribution intra and extracellular acidobasic equilibrium, maintaining osmotic pressure of the body fluids and normal neuromuscular irritability (Harper, 1997). Results (Tables $4,5 \mathrm{a} \& b)$ revealed a significant increase in calcium levels in diazinon exposed fish during both acute and chronic exposures, compared to the control group. These results were similar to those recorded by Logaswamy et al.(2007). The increased levels of blood calcium might be due to renal damage and dysfunction which in turn impaired the ability of fish to actively excrete excess of these ions through kidney as reported by Larsson et al.( 1976) . On the other hand, the results disagreed with those of Singh et al.(1997) and Lusková et al.(2002). This could be attributed to the use of propoxur "a carbamate pesticide" and the different concentration of Basudin EW600 (32.5 mg/L.), respectively. They also, disagreed with that of Thangavel et al. (2005) who recorded a marked decrease in serum calcium levels in O. mossambicus exposed to sub lethal concentrations of individual dimecron and ziram and combinaed 1: 4 mixture of both. The variation in the results may be due to variation in both fish species and concentration of the pesticides used.

Blood cortisol is the major corticosteroid hormone in fish and may have a significant effect on its dynamics (Wendelar Bonga, 1997; Mommsen et al., 1999). The serum cortisol results demonstrated in Tables (4,5a \& b.), revealed a significant increase in the exposed fish during the short and the long term of exposure compared to the control group. 
Table (4): Effect of acute diazinon exposure on some stress parameters and calcium ions of Clarias gariepinus

\begin{tabular}{|c|c|c|c|c|}
\hline Days & $\begin{array}{c}\text { AchE } \\
(\mathrm{u} / \mathrm{l})\end{array}$ & $\begin{array}{c}\text { Glucose } \\
(\mathrm{mg} / \mathrm{dl})\end{array}$ & $\begin{array}{c}\text { Cortisol } \\
(\mu \mathrm{g} / \mathrm{dl})\end{array}$ & $\begin{array}{c}\mathrm{Ca}^{++} \text {ions } \\
(\mathrm{mg} / \mathrm{dl})\end{array}$ \\
\hline Control & $547.40 \pm 45.15^{\mathrm{a}}$ & $62.63 \pm 6.34^{\mathrm{c}}$ & $8.27 \pm 0.96^{\mathrm{b}}$ & $6.47 \pm 0.49^{\mathrm{b}}$ \\
\hline $3^{\text {rd }}$ day & $371.50 \pm 67.72^{\mathrm{b}}$ & $109.03 \pm 12.72^{\mathrm{ab}}$ & $11.93 \pm 0.87^{\mathrm{a}}$ & $8.07 \pm 0.26 \mathrm{a}$ \\
\hline $5^{\text {th }}$ day & $306.30 \pm 42.72^{\mathrm{b}}$ & $133.40 \pm 6.59^{\mathrm{a}}$ & $13.10 \pm 0.36^{\mathrm{a}}$ & $8.37 \pm 0.63 \mathrm{a}$ \\
\hline $7^{\text {th }}$ day & $234.60 \pm 22.57^{\mathrm{b}}$ & $103.83 \pm 6.68^{\mathrm{b}}$ & $12.97 \pm 0.52^{\mathrm{a}}$ & $9.43 \pm 0.39 \mathrm{a}$ \\
\hline
\end{tabular}

Table (5a): Effect of chronic exposure to diazinon on some stress parameters and calcium ions of Clarias gariepinus

\begin{tabular}{|c|c|c|c|c|}
\hline Days & $\begin{array}{c}\text { AchE } \\
(\mathrm{u} / \mathrm{l})\end{array}$ & $\begin{array}{c}\text { Glucose } \\
(\mathrm{mg} / \mathrm{dl})\end{array}$ & $\begin{array}{c}\text { Cortisol } \\
(\mu \mathrm{g} / \mathrm{dl})\end{array}$ & $\begin{array}{c}\mathrm{Ca}^{++} \\
\text {ions } \\
(\mathrm{mg} / \mathrm{dl})\end{array}$ \\
\hline Control & $547.40 \pm 45.15^{\mathrm{a}}$ & $62.63 \pm 6.34^{\mathrm{d}}$ & $8.27 \pm 0.96^{\mathrm{c}}$ & $6.47 \pm 0.49^{\mathrm{c}}$ \\
\hline $3^{\text {rd }}$ day & $490.70 \pm 11.45^{\mathrm{ab}}$ & $70.83 \pm 4.17^{\mathrm{d}}$ & $12.87 \pm 0.66^{\mathrm{ab}}$ & $6.80 \pm 0.15^{\mathrm{c}}$ \\
\hline $7^{\text {th }}$ day & $391.00 \pm 45.15^{\mathrm{bc}}$ & $96.00 \pm 1.47 \mathrm{c}$ & $14.60 \pm 0.36^{\mathrm{a}}$ & $7.03 \pm 0.58^{\mathrm{bc}}$ \\
\hline $10^{\text {th }}$ day & $381.30 \pm 24.59^{\mathrm{bc}}$ & $109.60 \pm 4.89^{\mathrm{b}}$ & $10.70 \pm 0.44^{\mathrm{b}}$ & $7.70 \pm 0.44^{\mathrm{abc}}$ \\
\hline $14^{\text {th }}$ day & $374.17 \pm 16.83^{\mathrm{bc}}$ & $121.67 \pm 1.86^{\mathrm{a}}$ & $14.13 \pm 0.15^{\mathrm{a}}$ & $8.83 \pm 0.44^{\mathrm{a}}$ \\
\hline
\end{tabular}

Table (5b): Effect of chronic exposure to diazinon on some stress parameters and calcium ions of Clarias gariepinus

\begin{tabular}{|c|c|c|c|c|}
\hline Days & $\begin{array}{c}\text { AchE } \\
(\mathrm{u} / \mathrm{l})\end{array}$ & $\begin{array}{c}\text { Glucose } \\
(\mathrm{mg} / \mathrm{dl})\end{array}$ & $\begin{array}{c}\text { Cortisol } \\
(\mu \mathrm{g} / \mathrm{dl})\end{array}$ & $\begin{array}{c}\mathrm{Ca} \\
(\mathrm{mg} / \mathrm{dl})\end{array}$ \\
\hline $21^{\text {st }}$ day & $312.80 \pm 90.29^{\mathrm{c}}$ & $126.47 \pm 3.45^{\mathrm{a}}$ & $13.80 \pm 0.12^{\mathrm{a}}$ & $6.90 \pm 0.21^{\mathrm{c}}$ \\
\hline $28^{\text {th }}$ day & $338.43 \pm 14.24^{\mathrm{c}}$ & $132.50 \pm 2.48^{\mathrm{a}}$ & $14.77 \pm 1.65^{\mathrm{a}}$ & $7.37 \pm 0.52^{\mathrm{abc}}$ \\
\hline $35^{\text {th }}$ day & $289.50 \pm 25.98^{\mathrm{c}}$ & $128.27 \pm 1.05^{\mathrm{a}}$ & $14.17 \pm 0.71^{\mathrm{a}}$ & $7.10 \pm 1.01^{\mathrm{bc}}$ \\
\hline $42^{\text {nd }}$ day & $262.07 \pm 15.85^{\mathrm{c}}$ & $127.73 \pm 2.71^{\mathrm{a}}$ & $15.53 \pm 1.05^{\mathrm{a}}$ & $8.63 \pm 0.32^{\mathrm{ab}}$ \\
\hline
\end{tabular}

The obtained results agreed with that of Thangavel et al.(2005) and Cericato et al.(2008). The above data may be explained by the activation of hypothalamo- pituitary- inter renal axis with their release of steroid cortisol in blood stream due to stress (Ibrahim, 1992 and Reddy \& Leatherland,1998). Also, it could be attributed to the increase in osmotic water- influx, which may cause a cortisol elevation, to restore the hydromineral balance. This osmoregulatory dysfunction might be harmful perse ; and owing to sustained high cortisol level 
which may cause several deleterious physiological changes, affecting the immuno-competence, health status and survival of the fishes (Wendelaar Bonga, 1997). On the other hand, the results disagreed with those demonstrated by Maduenho \& Martinez (2008) who reported non significant alterations in plasma cortisol level of Prochilodus lineatus exposed to diflubenzuron (DFB). This difference could be attributed to fish species and pesticide variance.

Blood glucose is considered as indicator for stress response in fish (Abdel -Baky, 2001). The result of serum glucose are demonstrated in Tables (4-a \& b.). They showed a significant increase in all diazinon exposed fish groups. These results supported those of Haggag (2004) and Sweilum (2006). The hyperglycaemic condition induced by pesticides might be explained in part by inhibition of cholinesterase at neuro effector sites in the adrenal medulla, leading to hypersecretion of adrenaline and cortisol which stimulates the break down of glycogen to glucose (glycogenolysis) (Gupta,1974). This explanation is supported by the elevation in cortisol level recorded in this study. Also, in this respect, hyperglaecemia can be viewed as a physiological response of the fish to meet the critical need for energy under toxic stress. This need may be met by increased break down of liver and muscle glycogen as described by Ferrando and Andreu- Moliner (1991).The elevated glucose level observed may be also due to enhancement of the break down of liver glycogen due to reduced insulin activity. These findings agree with those of Wedemeyer (1996) and Reddy \& Leatherland (1998). In contrast, Mekkawy et al. (1996) and Agrahari et al. (2007) recorded a marked decrease in glucose levels of both $O$. niloticus and $C$. auratus exposed to atrazine and C. punctatus fish exposed to Monocrotophos.

AchE is sensitive to organophosphate and carbamates pesticides that are well known as potent (AchE) inhibitors (Van der Oost et al., 2003). So, plasma (AchE) activity could be used as a biomarker of exposure to pesticides, as it decreased in fish collected from sites contaminated by pesticides (Dorval et al., 2004). Regarding serum (AchE) results in Tables (4-5a\&b), revealed a significant inhibition of (AchE) in the exposed fish during the acute and chronic exposures compared to the control group. Also, the inhibition of (AchE) is correlated with exposure concentration, but not with exposure time as reviewed by Roex et al. (2003). Our results agreed with those of Rao (2006b); Guimarães et al. ( 2007); Cong et al., 2008; Cong et al., 2009). Also, it is more or less in agreement with those of (David et al., 2007), who recorded an increase in (AchE) activity of Cirrhinus mrigala fish exposed to $\mathrm{LC}_{50}$ of malathion (3 microl / L.) for 5 and 15 days but on the $25^{\text {th }}$ day of exposure all values approached the normal ones. This may be attributed to recuperation and adaptation phenomena.

In order to investigate the toxic effect of diazinon pesticide on the health status of C. gariepinus after its release from the fish body and to detect its public health significance on the human consumers, a clearance experiment has been 
carried out for 14 days during which different previously mentioned biochemical and residual parameters have been measured at $7^{\text {th }}$ day and $14^{\text {th }}$ day.

Regarding ALT and AST enzymes of the exposed C. gariepinus during the clearance period, results demonstrated in Table (6) revealed gradual decrease but still above the normal values. The results are supportive to those reported by Abou - Zeid et al. (1996) and Rao (2006 a\&b).

Regarding the results of total protein, albumin, globulin and $\mathrm{A} / \mathrm{G}$ ratio (Table 6) after the recovery period, the total protein, albumin and globulin values increased but the values of $\mathrm{A} / \mathrm{G}$ ratio decreased at the $7^{\text {th }}$ day and started to increase again at the $14^{\text {th }}$ day of clearance. These results support those of Abou - Zeid et al. (1996) but disagreed with those of Sancho et al. (1998) who mentioned that levels of proteins did not approach the normal values. This may be attributed to time of clearance (192 h.) and different fish species, (Anguilla anguilla).

A similar pattern of urea, uric acid and creatinine values had been detected during the clearance period (Table 6). Results disagreed with Radwan \& El Said (2006), which may be due to variance in both fish species \& concentration of pesticide used.

Table (6): Liver and kidney functions parameters of Clarias gariepinus during clearance period (2 weeks):

\begin{tabular}{|c|c|c|c|c|c|c|c|c|c|}
\hline Days & $\begin{array}{c}\text { (AST) } \\
(\mathrm{u} / \mathrm{l})\end{array}$ & $\begin{array}{c}\text { (ALT) } \\
(\mathbf{u} / \mathbf{l})\end{array}$ & $\begin{array}{c}\text { Total } \\
\text { protein } \\
\text { (g/dl) }\end{array}$ & $\underset{\text { (g/dl) }}{\text { Albumin }}$ & $\begin{array}{l}\text { Globulin } \\
\text { (g/dl) }\end{array}$ & A/G ratio & $\begin{array}{c}\text { Creatinine } \\
(\mathrm{mg} / \mathrm{dl})\end{array}$ & $\begin{array}{c}\text { Urea } \\
\text { (mg/dl) }\end{array}$ & $\begin{array}{c}\text { Uric acid } \\
\text { (mg/dl) }\end{array}$ \\
\hline 0 day $^{*}$ & $31.63 \pm 1.31^{\mathrm{a}}$ & $30.10 \pm 1.01^{\mathrm{a}}$ & $3.13 \pm 0.09^{\mathrm{a}}$ & $1.03 \pm 0.12^{\mathrm{a}}$ & $2.10 \pm 0.12^{\mathrm{a}}$ & $0.50 \pm 0.10^{\mathrm{a}}$ & $0.83 \pm 0.09^{\mathrm{a}}$ & $19.10 \pm 0.68^{\mathrm{a}}$ & $3.17 \pm 0.24^{\mathrm{a}}$ \\
\hline $7^{\text {th }}$ day** & $25.60 \pm 1.47^{\mathrm{b}}$ & $23.70 \pm 0.96^{\mathrm{b}}$ & $3.20 \pm 0.25^{\mathrm{a}}$ & $1.17 \pm 0.03^{\mathrm{a}}$ & $2.03 \pm 0.22^{\mathrm{a}}$ & $0.59 \pm 0.05^{\mathrm{a}}$ & $0.67 \pm 0.03^{\mathrm{a}}$ & $17.63 \pm 0.92^{\mathrm{a}}$ & $2.97 \pm 0.12^{\mathrm{a}}$ \\
\hline $\begin{array}{c}14^{\text {th }} \\
\text { day*** }\end{array}$ & $22.47 \pm 1.19^{b}$ & $22.53 \pm 1.15^{\mathrm{b}}$ & $3.33 \pm 0.17^{\mathrm{a}}$ & $1.30 \pm 0.06^{\mathrm{a}}$ & $2.03 \pm 0.12^{\mathrm{a}}$ & $0.64 \pm 0.03^{\mathrm{a}}$ & $0.53 \pm 0.08^{\mathrm{a}}$ & $16.30 \pm 1.22^{\mathrm{a}}$ & $2.87 \pm 0.12^{\mathrm{a}}$ \\
\hline
\end{tabular}

$*$ : values at the end of chronic exposure to $1 / 10$ LC 50 value for 42 days.

**: values 7 days after putting of fish in diazinon free water.

***: values 14 days after putting of fish in diazinon free water.

Concerning stress indicators and calcium ions, the results demonstrated in Table (7) showed that the levels of glucose and cortisol hormone are still above the control levels even after the recovery period. The results of glucose agreed with that of Sancho et al. (1998), but disagreed with Abou-Zeid et al. (1996) who recorded that the serum glucose level of Clarias lazera exposed to sublethal concentration $\left(0.1 \mathrm{LD}_{50}\right)$ of a group of pesticides [two herbicides: glyphosate and paraquate; two insecticides: malathion and cyanphose and one nematocide, lindane] was partially recovered after the recovery period. This may be due to the low concentrations of the different pesticides used. On the other hand, the results of AchE remained significantly depressed, which is nearly similar to that of Sancho et al.(1997) \& Solomon et al.(2000) but disagreed with those of Rao (2006 a\& b). This may be attributed to different fish species, (Oreochromis 
mossambicus). However, the results of calcium ions did not return to the normal values after the recovery period.

Table (7): Some stress parameters and calcium ions of Clarias gariepinus during the clearance period

\begin{tabular}{|c|c|c|c|c|}
\hline Days & $\begin{array}{c}\text { AchE } \\
(\mathrm{u} / 1)\end{array}$ & $\begin{array}{c}\text { Glucose } \\
(\mathrm{mg} / \mathrm{dl})\end{array}$ & $\begin{array}{c}\text { Cortisol } \\
(\mu \mathrm{g} / \mathrm{dl})\end{array}$ & $\begin{array}{c}\mathrm{Ca}^{++} \text {ions } \\
(\mathrm{mg} / \mathrm{dl})\end{array}$ \\
\hline 0 day $^{*}$ & $262.07 \pm 15.85^{\mathrm{b}}$ & $127.73 \pm 2.71^{\mathrm{a}}$ & $15.53 \pm 1.05^{\mathrm{a}}$ & $8.63 \pm 0.32^{\mathrm{a}}$ \\
\hline $7^{\text {th }}$ day** $^{* *}$ & $384.50 \pm 53.22^{\mathrm{a}}$ & $108.73 \pm 4.13^{\mathrm{b}}$ & $14.53 \pm 0.09^{\mathrm{a}}$ & $7.97 \pm 0.23^{\mathrm{ab}}$ \\
\hline $14^{\text {th }}$ day*** & $395.90 \pm 19.75^{\mathrm{a}}$ & $99.17 \pm 0.38^{\mathrm{b}}$ & $11.60 \pm 0.61^{\mathrm{b}}$ & $7.27 \pm 0.49^{\mathrm{b}}$ \\
\hline
\end{tabular}

Concerning the residual effect of diazinon in gills, liver and muscles of exposed fish, results are demonstrated in Table (8). They revealed that the accumulation levels of diazinon in fish tissues were increased by the elapse of time throughout the chronic toxicity. The high residue levels of diazinon in all groups of exposed fish was detected in gills then muscles and followed by liver during the chronic exposure. These results support the findings of Sancho et al. (1997) and Munshigeri \& David (2004) where, the gills are the primary site of uptake of water-borne pollutants, but they disagreed with those of Radwan \& El - Said (2006) and Sweilum (2006) who mentioned that the pesticide residues in liver was higher than in gills or muscles, which had the lowest residues for these pesticides. This may be attributed to the fact that the liver is the primary organ for detoxification or to the different fish species and concentration of pesticide used. On the other hand, the residue levels of diazinon in liver, gills and muscles were decreased during the recovery period after the $14^{\text {th }}$ day more than the at $7^{\text {th }}$ day, Therefore, further time of recovery period is needed to determine the most safe and suitable time for consumption of previously exposed fish.

Table (8): Diazinon residues in liver, gills and muscles of $C$. gariepinus during the chronic exposure and throughout the clearance period:

\begin{tabular}{|c|c|c|c|}
\hline Day & Liver & Gills & Muscles \\
\hline $7^{\text {th }}$ day & $0.0699 \pm 0.0044$ & $0.3070 \pm 0.0195$ & $0.1389 \pm 0.0089$ \\
\hline $14^{\text {th }}$ day & $0.0700 \pm 0.0045$ & $0.3779 \pm 0.0239$ & $0.19811 \pm 0.0116$ \\
\hline $21^{\text {st }}$ day & $0.12367 \pm 0.0078$ & $0.4968 \pm 0.0316$ & $0.2074 \pm 0.0132$ \\
\hline $28^{\text {th }}$ day & $0.13931 \pm 0.0088$ & $0.5234 \pm 0.0332$ & $0.2275 \pm 0.0144$ \\
\hline $35^{\text {th }}$ day & $0.1474 \pm 0.0043$ & $0.5265 \pm 0.0334$ & $0.3879 \pm 0.0246$ \\
\hline $42^{\text {nd }}$ day & $0.16097 \pm 0.0102$ & $0.5728 \pm 0.0363$ & $0.5823 \pm 0.0368$ \\
\hline 7 days* & $0.0936 \pm 0.0335$ & $0.4347 \pm 0.0277$ & $0.5249 \pm 0.0366$ \\
\hline 14 days** & $0.0361 \pm 0.0313$ & $0.2869 \pm 0.0513$ & $0.4063 \pm 0.0246$ \\
\hline
\end{tabular}

*: values 7 days after putting of fish in diazinon free water (clearance).

**: values 14 days after putting of fish in diazinon free water(clearance). 


\section{REFERENCES}

Abdel - Baky, T.E. (2001). Heavy metals concentrations in the catfish, Clarias gariepinus (Burchell, 1822) from River Nile, El - Salam canal and lake Manzala and their impacts on cortisol and thyroid hormones. Egypt. J. Aquat. Biol. \& Fish., 5 (1): 79 - 98.

Abou - Zeid, M.M.; Zahkouk, S.A.; El - Nabarawy, S.K. and El - Zawahry, E.I. (1996). Some haematological and physiological changes induced by certain pesticides to the Nile catfish, Clarias lazera (Claridae). Al Azhar Bull. Sci. Egypt, 7 (1): 799 - 804.

Adams, S.M. and Greeley, M.S. (2000). Ecotoxicological indicators of water quality using multi - response indicators to assess the health of aquatic ecosystems . Water Air Soil Pollut., 123: $103-115$.

Adedeji, O.B. ; Adedeji, A.O. ; Adeyemo,O.K. and Agbede, S.A. (2008). Acute toxicity of diazinon to the African catfish, Clarias gariepinus. African, J. Biotechnol., 7(5): $651-654$.

Agrahari, S.; Pandey, K.C. and Gopal, K. (2007). Biochemical alterations induced by monocrotophos in the blood plasma of fish Channa punctatus (Bloch). Pest. Biochem. Physiol., 88 (3): 268 -272

Amlacher, E. (1970). Text book of fish diseases" pp. 135 - 137. publication, 1970, Jercy, USA.

Arunachalam, S.; Jeyalakshmi, K. and Aboobucker, S. (1980). Toxic and sublethal effects of carbaryl on a freshwater fish, Mystus rittatus (Bloch). Arch. Environ. Contam. Toxicol., 9 (3): 307 - 316.

Arunachalam, S. and Palanichamy, S. (1982). "Sublethal effects of carbaryl on surfacing behaviour and food utilization in the air-breathing fish, Macropodus cupanus." Physiol. \& Behav. J. 29(1):23-27.

Bailey,H. C.; Deanovic, L.; Reyes, E.; Kimball ,T.; Larson, K.; Connor, V. and Hinton, D.E.(2000). Diazinon and chlorpyriphos in urban water ways in northern California ,USA. Environ. Toxicol. Chem.19: 82 - 87.

Barham, D. and Trinder, P. (1972). Analyst, 97: 142pp. 
Baskaran, P. and Palanichamy, S. (1990). Impact of agricultural (ammonium chloride) fertilizer on physiology and biochemistry of freshwater teleost fish, Oreochromis mossambicus. J. Ecobiol., 2: 97-106

Biggs, H.G. and Moorehead, W.R. (1974). Clin. Chem., 20:1458- 1460.

Bradbury, S.P.; Makim, J.R. and Coats, J.R. (1987). Physiological responses of rainbow trout, Salmo gairdneri to acute fenvalerate intoxication. Pestic. Biochem. Physiol., 27: 275 - 285.

Burkepile, D.E. ; Moore, M.T. and Holland, M.M. (2000). The susceptibility of five non target organisms to aqueous diazinon exposure. Bull. Envion. Contam. Toxicol., 64:114-121

Cericato, L.; Neto, J.G.; Fagundes, M.; Kreutz, L.C.; Quevedo, R.M.; Finco, J.; da Rosa, J.G.; Koakoski,G.; Centenaro, L.; Pottker, E.; Anziliero, D. and Barcellos, L. J. (2008). Cortisol response to acute stress in Judiná Rhamdiaquelen acutely exposed to sublethal concentrations of agrichemicals. Comp. Biochem. \& Physiol., 148(C) : 281 - 286.

Coles, E.H. (1974). "Vet. Clinical pathology" $2^{\text {nd }}$ Ed. W.B. Saudners Co. Philadelphia and London.

Coles, E.H. (1986). Kidney functions In: Veterenary Clinical Pathology .W.B. Sunders Company, pp171 - 202

Cong, N.V.; Phuong, N.T. and Bayley, M. (2008). Brain cholinesterase response in the snakehead fish Channa striata after field exposure to diazinon.Ecotoxicol. Environ. Saf., 71: $314-318$.

Cong, N.V.; Phuong, N.T. and Bayley, M. (2009). Effects of repeated exposure of diazinon on cholinesterase activity and growth in snakehead fish (Channa striata) Ecotoxicol. Environ. Saf., March 2009, 72 (3): 699703

David, M.; Shivakumar, H.B.; Ramesh, H.; Marigoudar, S.R. and Naik, V.R. (2007). Hepatotoxic potential of malathion in the freshwater teleost, Cirrhinus mrigala (Hamilton). J. Basic. Clin. Physiol. Pharmacol., 18 (4): $307-314$.

Dede, E.B. (1992). Effect of lindane pretreatment on dichlorvos toxicity in vitro, in vivo. $\mathrm{Ph}$ D. thesis, ABuzaria. 
Devlaming ,V.; Connor,V.; Digiorgio, C.; Bailey, H.C.; Deanovic, L.A.and Hinton, D.E. (2000). Application of whole effluent toxicity test procedures to ambient water quality assessment Environ. Toxicol. chem., 19:42-62

Dorval, J.; Leblond V.; Deblois, C. and Hontela, A. (2004). "Oxidative stress and endocrine endpoints in white sucker (Catostomus commersoni) from a river impacted by agricultural chemicals." Environ. Toxicol.\& Chemistry J., 24 (5): 1273-1280.

Dumas, B.T. and Biggs, H.G. (1972). I.N. Standard Methods of clinical chemistry. Vol. 7, Academic press, New York, pp.175.

Dutta, H.M.; Munshi, J.S.; Dutta, G.R. ; Singh, N.K. ; Adhikari, S. and Richmonds, C. (1995). Age related differences in the inhibition of brain acetylcholinesterase activity of Heteropneustes fossilis (Bloch) by malathion. Comp. Biochem. Physiol., A.11 (2): 331 - 334.

EPA. (2004). Interim Deregistration Eligibility Decision. Diazinon. United states Environmental protection Agency, office of prevention, pesticides and Toxic substances $7508 \mathrm{c}$.

Fabiny, D.L. and Eriinghausen, G. (1971). Clin. Chem., 17 : 696pp.

Ferrando, M.D. and Andreu - Moliner, E. (1991). Effect of lindane on the blood of a freshwater fish. Bull. Environ. Contam. Toxicol., 47 : 465 -470 .

Freeman, H.C.; Sangalang, G.B.; Uthe, J.F.; Garside, E.T. \& Daye, P.G. (1983). "A histopathological examination and analysis for polychlorinated hydrocarbons in inshore Atlantic cod (Gadus morhae)." Arch. Environ. Contam. Toxicol.J., 12: 627-632.

Fulton, M.H. and Key, P.B. (2001). Acetylcholinesterase inhibition in estuarine fish and invertebrates as an indicator of organophosphorous insecticide exposure and effects. Environ. Toxicol. Chem., 20: 37 - 45.

Garfitt, S. J.; Jones, K.; Mason, H.J. and Cocker, J. (2002). Exposure to the organophosphate diazinon: data from a human volunteer, study with oral and dermal doses. Toxicol. Lett., 134: $105-113$.

Gornal, A.G.; Bardawil, C.J. and David, M.M. (1949). J. Biol. Chem., 177: 751pp. 
Guimarães, A.T.; Silva de Assis, H.C. and Boeger, W. (2007). The effect of trichlorfon on acetylcholineaterase activity and histopathology of cultivated fish Oreochromis niloticus. Ecotoxicol.Environ. Saf., 68 (1): $57-62$.

Gupta, P.K. (1974). Malathion induced biochemical changes in rats. Acta pharmacologia et Toxicologia., 35: 191-194

Haggag, N.Z. (2004). Physiological studies on the changes induced by some non - traditional pesticides to the Nile catfish. M.V.Sc. thesis. Girls college, Ain shams Univ., Cairo.

Hamm, J.T. ;Wilson, B.W. and Hinton, D.E. (1998). Organophosphate- induced acetylcholinesterase inhibition and embryonic retinal cell necrosis in vivo in the teleost Oryzias latipes. Neurotoxicology, 19: $853-870$.

Hanna, M.I. and Sahar, A.El-Madawy (2007). Clinical and biochemical pictures of carbofuran toxicity in Clarias gariepinus. J. Environ. Sci., 33 (2): $67-91$.

Harper, H.A. (1997). Přehled fysiologické chemie . Avicenum, Praha, 639pp.

Heath, A.G. (1995). Water pollution and fish physiology. CRC Press Inc. Boca Raton, Florida.

Henry, J.B.; Todd; Sanford; David Shon (1974). Clinical Diagnosis and measurement by laboratory methods. $16^{\text {th }}$ ed., W.B. Saunders and Co., Philadelphia PA., 260 pp.

Hernandez, T. and Couslon, R.A. (1967). Amino acid execretion in the alligator. Comp. Biochem. Physiol., 23: 775 - 784.

Hussein, S.Y.; El-Nasser, M.A and Ahmed, S.M. (1996). Comparative studies on the effect of herbicide atrazine on freshwater fish Oreochromis niloticus and Chrysichthye auratus at Assuit, Egypt. Bull. Envion. Contam. Toxicol., 57: 503 - 510.

Ibrahim, A.T. (1992). Effects of some industrial pollutants on Tilapia nilotica Proc. $2^{\text {nd }}$ conf. Fac. Vet. Med., Cairo Univ., pp.47-51.

John, S.; Kale, M.; Rathoreand, N. and Bhatnagar, D. (2001). Protective effect of vitamin $\mathrm{E}$ in dimethoate and malathion induced oxidative stress in rat erythrocytes . J. Nutr. Biochem., 12: $500-504$. 
Kavitha, P. and Rao, J.V. (2007). Oxidative and locomotor behaviour response as biomarkers for assessing recovery status of mosquito fish Gambusia affinis after lethal effect of an organo- phosphate pesticide, monocrotophos. Pest. Biochem. Physiol., 87: $182-188$.

Kendel, M. and Bottger, R. (1967). Klin. Wschr., 45: 325 - 327.

Khallaf - Allah, S.S. (1998). Screening the effect of water pollution with some pesticides on the Immuno Response in Oreochromis niloticus (Tilapia nilotica) fish. Med. J. Giza., 46 (4B): 883 - 893.

Köprücü, S.S.; Köprücü, k.; Ural, M.Ş.; İspir Ü. and Pala, M. (2006). Acute toxicity of organophosphorous pesticide diaz- inon and its effect on behavior and some haemato- logical parameters of fingerling European catfish, Silurus glanis L. Pest. Biochem. Physiol., 86:99-105.

Larsson, A; Bengtsson, B.E. and Svanbeg, O. (1976). Some haematological and biochemical effects of cadmium on fish. In A.P.M. Lockwood (Ed.), Effects of pollutants on aquatic organisms, pp: $35-45$. Cambridge, UK: Cambridge Univ. Press.

Logaswamy, S.; Radha, G.; Subhashini, S. and Logankumar, K. (2007). Alteration in the levels of ions in blood and liver of freshwater fish, Cyprinus carpio. var. communis exposed to dimethoate . Environ. Monit. Assess., 131 (1- 3): 439- 444.

Lusková, V. ; Svoboda, M. and Kolářová, J. (2002). The effect of diazinon on blood plasma biochemistry in carp Cyprinus carpio L. ACTAVET. BRNO., 71 : 117- 123.

Máchová, J.; Prokeš, M.; Svobodová, Z.; Žlábek,V.; Peňáz, M. and Baruš, V. (2007). Toxicity of diazinon 60 EC for Cyprinus carpio and Poecilia reticulata. Aquacult. Int., 15: $267-276$

Maduenho, L.P. and Martinez, C.B. (2008). Acute effects of diflubenzuron on the freshwater fish Prochilodus lineatus. Comp. Biochem. Physiol., 148(C): $265-272$.

Marie, M.A.; Mohamed, H.A. and El - Badawy, A. A. (1998).Physiological and biochemical responses of the common carp, Cyprinus carpio to an organophosphorous insecticide "profenofos". Egypt. J. Zool., 31: 279-302. 
Mekkawy, I.A.; Hussein, S.Y.; Abdel - Nasser, M. and Ahmed,S.M. (1996). Comparative studies on the effects of herbicide atrazine on some blood constituents and protein electrophoretic patterns of Oreochromis niloticus and Chrysichthyes auratus. Assuit. J. Egypt. Ger. Soc. Zool., 19 (A):283 - 319 .

Mills,P.A; Barhara, A.B.; Laverne, R.K. and Jerry, A. B.(1972). Elution sovent systems for florisil clean up in organochlorine pesticides analysis. JAOAC, 5:39-43.

Mommsen, T.P. and Walsh, P. J. (1992). Biochemical and environmental perspectives on nitrogen metabolism in fishes . Experientia, 48: $583-593$

Mommsen, T.P.; Vijayan, M.M. and Moon, T.W. (1999). Cortisol in teleosts: dynamics, mechanisms of action and metabolic regulation. Rev. Fish Biol. Fish., 9: $211-268$.

Mushigeri, S.B. and David, M. (2004). Accumulation of fenvalerate and related changes in lactate and succinate dehydrogenases activity in functionally different tissues of the freshwater fish, Cirrhinus mrigala (Hamilton). J. Basic. Clin. Physiol. Pharmacol., 15 (3 - 4): 143 - 152.

Oh, H.S.; Lee, S.K.; Kim, Y.H. and Roh, J.K. (1991). Mechanism of selective toxicity of diazinon to killifish (Oryzias latipes) and loach (Misgumus anguillicaudatus). Aquat. Toxicol. Risk Assess., 14: 343-353.

Palacio, J.A.; Henao, B.; Vélez, J.H.; González, J. and Parra, C.M. (2002). Acute toxicity and bioaccumulation of pesticide diazinon in red tilapia Oreochromis niloticus x Mossambicus albino. Environ.Toxicol., 17 (4): $334-340$.

Palanivelu, V.; Vijayavel, K.; Ezhilarasibalasubramanian, S. and Balasubramanian, M.P. (2005). Influence of insecticide (Cartap Hydrochloride) from the marine polychaete on certain enzyme systems of the freshwater fish Oreochromis mossambicus. J. Environ. Biol., 26: $191-196$.

Parums, D.V. (1996). Disease of the Liver, Biliary tract and exocrine pancrease In: Essential Clinical Pathology. Black well Science, pp. $43-47$. 
Radwan, O.A. and El -Said, M.M. (2006). Biochemical studies on residues of two different formulations of profenfos insecticide in O.niloticus. J. Biol Chem. Environ Sci., 1(3): 491 - 519.

Rao, J.V. (2006 a). Toxic effects of novel organophosphorous insecticide (RPR - v) on certain biochemical parameters of euryhaline fish Oreochromis mossambicus. Pest. Biochem. Physiol., 86 (2): 78 - 84.

Rao, J.V. (2006 b). Sublethal effects of an organophosphorous insect - icide (RPR-II) on biochemical parameters of tilapia Oreochromis mossambicus. Comp. Biochem. Physiol. Part (C) Toxicol. Pharmacol., 143 (4): $492-49$.

Rao, J.V. (2006c). Biochemical alterations in euryhaline fish, Oreochromis mossambicus exposed to sublethal concentrations of an organophosphorous insecticide, monocrotophos. Chemo., 65 (10): $1814-1820$.

Reddy, P.K. and Leatherland, J.F. (1998). Stress Physiology, In: Fish disease and disorders, Vol.2 Non - infections Disorders. (Eds. Leatherland, J.F.and Woo, P.T.K.), Cabi Pub. 1998: pp.279 - 301.

Reitman, S. and Frankel, S. (1957). A colorimetric method for the determination of serum glutamic oxalacetic and glutamic pyruvic transaminases. Amer. J. Clin. Pathol., 28: 56 - 63.

Roex, E.W.; Keijzers, R. and Van Gestel, C.A. (2003). Acetyl cholinesterase inhibition and increased food consumption rate in the zebra fish, Danio rerio after chronic exposure to parathion. Aqu. Toxicol., 64 (4): 451-460.

Safi, J.M.D. (1996). "Liver enzymes as biomakers of exposure to organophosphorus pesticides." Alex. Sci. Ech. J, 17 (4): 351-360.

Sancho, E.; Ferrando, M.D. and Andreu, E. (1997). Response and recovery of brain acetylcholinesteraseactivity in the European eel, Anguilla anguilla exposed to fenitrothion. Ecotoxicol. \& Environ. Saf., 38: 205-209.

Sancho, E.; Ferrando, M.D.; Fernández, C. and Andreu, E. (1998). Liver energy metabolism of Anguilla anguilla after exposure to Fenitrothion. Ecotoxicol. \& Environ. Saf., 41 (2):168 - 175. 
Singh, N.N.; Das, V.K. and Srivastava, A.K. (1997). Chronic toxicity of propoxur on carbohydrate, proteinand serum electrolyte levels in catfish, Heteropneustes fossilis . Biomed. \& Environ. Sci. J., 10 (4): 408-414.

Solomon, S.S.; Shao - nan, L.I. and De - Fan, F. (2000). In vivo inhibition and recovery of brain acetylcholine-esterase in Topmouth gudgeon Pseudorasobora parva following exposure to Fenitrothion. J. Zhejiang univ.(Sci.), 1(4): $448-455$.

SPSS (2004). "Statistical and package for social science, SPSS for windows release 14.0.0, 19 June, 2004." Standard version, copyright SPSS Inc., 1989 - 2004, All rights Reserved, copyright 2 SPSS Inc.

Sweilum, M.A. (2006). Effect of sublethal toxicity of some pesticides on growth parameters,haematological properties and total production of Nile tilapia, Oreochromis niloticus $L$. and water quality of ponds. Aquacul. Res. Oxford, UK., 37 (11):1079 - 1089.

Thangavel, P.; Sumathiral, K.; Karthikeyan, S. and Ramaswamy, M. (2005). Endocrine response of the freshwater teleost, Sarotherodon mossambicus (Peters) to dimecron exposure. Chemo., 61(8): $1083-1092$.

Tomlin, C.D.S.(1997). The Pesticide Manual, British Crop protection Council, pp. $354-356$

Trinder, P. (1959). "Determination of Blood Glucose using 4Aminophenazone". J. Clin. Pathol., 22: 246pp .

Üral, M.S. and Koprucu, S.S. (2006). Acute toxicity of dichlorvos on fingerling European catfish Silurus glanis L. Bull. Envion. Contam. Toxicol., 76 (5): 871- 876 .

Van der Oost, R.; Beyer, J. and Vermeulen, N.P.E. (2003). Fish bioaccumulation and biomarkers in environmental risk assessment: a review. Environ. Toxicol. Pharmacol., 13: 57 - 149.

Vasanthi, R.; Baskaran, P. \& Palanichamy, S. (1990). Influence of carbofuran on growth and protein conversion efficiency in some freshwater fishes. J. Ecobiol., 2: $85-88$. 
Watterson, A.E. (1999). Regulating pesticides in the UK : a case study of risk management problems relating to the organophosphate diazinon. Toxicol. Lett., pp.107 : 241

Wedemeyer, G.A. (1996). Physiology of Fish in Intensive Culture Systems. 232, Chapman and Hall, 115 Fifth Avenue New York, 1996:232 pp.

Wendelaar Bonga, S.E. (1997). The stress response in fish .Physiol. Rev., 77: $591-625$.

Yalow, R. and Berson, S. (1971). Introduction and general considerations. IN; WD, Doughady WH (eds): Principles of competitive protein binding assays. J. b. Lipincott Co., Philadelphia, pp.1- 19

Zinkl, J.G.; Lockhart, W.L.; Kenny, S. A. and Ward, F.J. (1991). The effects of cholinesterase inhibiting insecticides on fish. In CholineateraseInhibiting Insecticides (P.Mineau, Ed.), pp. 234 - 254. Elsevier, New York. 


\section{LEGEND OF FIGURES}

Fig. 1: Photo showing abnormal fading of skin colouration of Clarias gariepinus exposed to $1 / 10$ of $\mathrm{LC}_{50}$ of diazinon for 6 weeks.

Fig. 2: Photo showing severe distension of the gall bladder with liver enlargement in Clarias gariepinus exposed to $1 / 10$ of $\mathrm{LC}_{50}$ of diazinon for 6 weeks.

Fig. 3: Photo showing congestion and haemorrhage in the internal organs of Clarias gariepinus exposed to $1 / 2$ of $\mathrm{LC}_{50}$ of diazinon for 1 week.

Fig. 4: Photo showing haemorrhage in the testis of Clarias gariepinus exposed to $1 / 10$ of $\mathrm{LC}_{50}$ of diazinon for 6 weeks.

Fig. 5: Photo showing haemorrhage in the spleen and kidney of Clarias gariepinus exposed to $1 / 10$ of $\mathrm{LC}_{50}$ of diazinon for 6 weeks.

Fig. 6: Photo showing distension of the gall bladder with marked liver enlargement in Clarias gariepinus exposed to $1 / 10$ of $\mathrm{LC}_{50}$ of diazinon for 6 weeks. 

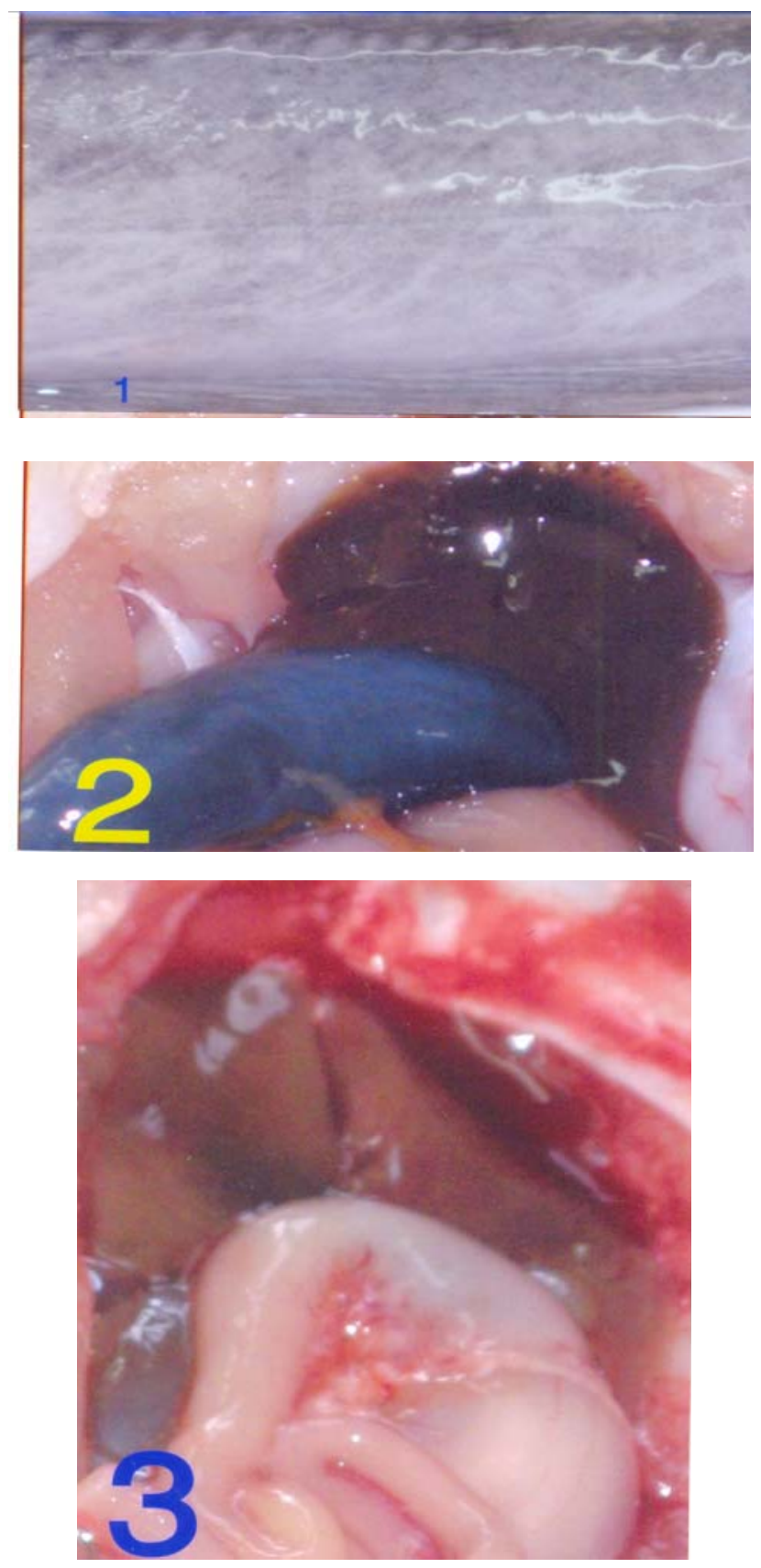

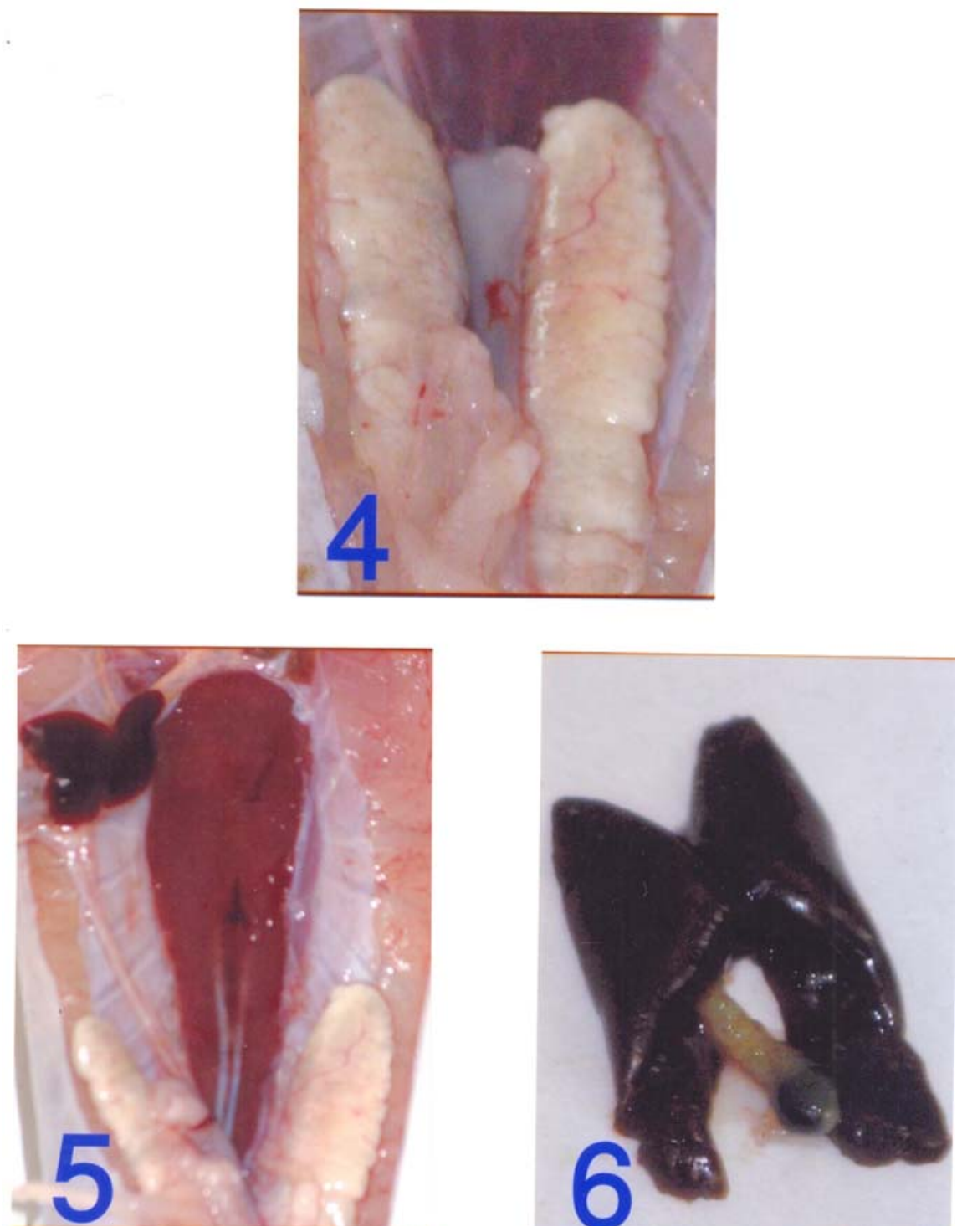